\title{
9. Corruption and the Concept of Culture: Evidence from the Pacific Islands
}

\author{
Peter Larmour
}

\section{Ideas about culture}

Ideas about 'culture' have often been used to explain or excuse acts of corruption. Gift-giving, it is sometimes said, is 'part of our culture', and outsiders should not confuse it with bribery or corruption. Such a relativistic approach has been strongly criticised by academic writers on corruption such as Syed Alatas in his classic Sociology of corruption (1968), and by activists like Transparency International (TI).

Alatas sees cultural relativism as another kind of Western naivety and condescension towards non-Western societies. The West, he argues, imagines the latter societies as incapable of telling right from wrong, a notion that Alatas thoroughly disproves in the course of his study by providing copious evidence of concern about abuse of public office from different historical periods dating back to ancient Rome, and different cultural traditions (Muslim and Chinese). Leaders violating norms knew those local norms existed. Cultural practices are used for the purposes of corruption rather than being the cause of corruption (Alatas, 1968, pp. 96-7).

More recently, TI has taken a robust stand against what it calls the 'myth' or 'excuse' of culture. Its influential Source book 2000 quotes one of the organisation's founding fathers, Olusegun Obasanjo, who went on to be elected President of Nigeria (Pope, 2000). Talking of the distinction between gifts and bribes, Obasanjo said:

I shudder at how an integral aspect of our culture could be taken as the basis for rationalising otherwise despicable behaviour. In the African concept of appreciation and hospitality, the gift is usually a token. It is not demanded. The value is usually in the spirit rather than in the material worth. It is usually done in the open, and never in secret. Where it is excessive, it becomes an embarrassment and it is returned. If anything, corruption has perverted and destroyed this aspect of our culture. (p. 8) 
Nevertheless, ideas linking culture with corruption won't go away easily. TI is an international organisation; whatever universalistic beliefs it holds, in practice it has to defer to claims of national and cultural difference. Meanwhile, ideas about culture have become increasingly influential in the social sciences, particularly in the field of cultural studies.

This chapter suggests how concepts of culture in general-and gift-giving in particular - may still be useful in understanding corruption and the problems associated with controlling it. It draws for empirical evidence on a series of reports on national integrity systems (NIS) in the Pacific Islands. The reports follow a standard template provided by TI, which asked about the existence and performance of various aspects of each country's 'national integrity system': the executive, the legislature, the auditor-general, civil society, and so on (Larmour \& Barcham, 2006). The authors of the reports were also asked to comment generally on the corruption situation in each country. For 12 of the 14 reports, the authors were specifically asked to comment on the role played by culture; the two remaining authors discussed culture without being prompted.

The Pacific Islands consist of 14 small countries, ranging in population from 1600 to six million, with a median of about 100000 inhabitants. The region is typically divided into three main 'culture areas': Micronesia to the north-west; Melanesia to the south-west; and Polynesia to the east (see Table 9.1). All but two of these 14 countries are parliamentary democracies. The two exceptions are Tonga, where the government is still responsible to a hereditary monarch rather than the legislature, and Fiji, which has been ruled by a military government since a coup in December 2006.

The region has also been important for Western study of anthropology, providing evidence for Marcel Mauss's classic study The gift (2002 [1950]) and other key texts in the discipline. In each country, arguments about the role of custom and tradition are an important part of everyday life and politics, including discussions about corruption.

Local cultural values show little sign of going away under pressures of colonialism or (now) globalisation. Marshall Sahlins has analysed the way Pacific Islanders use introduced materials to amplify their indigenous ways of life rather than abandon them, although he concedes they may eventually do the latter (1999). Chris Gregory talked about the 'efflorescence' of traditional culture on contact with Western goods that allowed people to have bigger funerals, wider circuits of exchange, more costly political campaigns and more remittances than ever before (1982). The upsurge of anxiety about corruption may reflect this upsurge in the volume and visibility of traditional practices, amplified by cash and new technology. 
Table 9.1 Pacific Islands Population and Political Status

\begin{tabular}{|c|c|c|}
\hline Name & $\begin{array}{r}\text { Population } \\
\text { (mid-2011 estimate) }\end{array}$ & Political status \\
\hline \multicolumn{3}{|l|}{ Melanesia } \\
\hline Fiji Islands & 851745 & Independent 1970 \\
\hline Papua New Guinea & 6888297 & Independent 1975 \\
\hline Solomon Islands & 553254 & Independent 1979 \\
\hline Vanuatu & 251784 & Independent 1980 \\
\hline \multicolumn{3}{|l|}{ Micronesia } \\
\hline $\begin{array}{l}\text { Federated States of } \\
\text { Micronesia }\end{array}$ & 102360 & $\begin{array}{r}\text { Free association with the United } \\
\text { States }\end{array}$ \\
\hline Kiribati & 102697 & Independent 1979 \\
\hline Marshall Islands & 54999 & $\begin{array}{r}\text { Free association with the United } \\
\text { States }\end{array}$ \\
\hline Nauru & 10185 & Independent 1968 \\
\hline Palau & 20643 & $\begin{array}{r}\text { Free association with the United } \\
\text { States }\end{array}$ \\
\hline \multicolumn{3}{|l|}{ Polynesia } \\
\hline Cook Islands & 15576 & $\begin{array}{r}\text { Free association with New } \\
\text { Zealand }\end{array}$ \\
\hline Niue & 1446 & $\begin{array}{r}\text { Free association with New } \\
\text { Zealand }\end{array}$ \\
\hline Sāmoa & 183617 & Independent 1962 \\
\hline Tonga & 103682 & Never colonised \\
\hline Tuvalu & 11206 & Independent 1978 \\
\hline
\end{tabular}

Source: Secretariat of the Pacific Community (2012). Population estimates and projections for several years. Pocket statistical summary 2011. Nouméa: Secretariat of the Pacific Community.

Each country in the region is dependent to some degree on foreign aid, loans from international development banks and, in Fiji's case, concessionary access to the European Union for its sugar exports. These donors, banks and international organisations have become increasingly vocal about 'good governance' and increasingly willing to insist that Pacific Island governments meet the standards they set as a condition for their grants, loans and concessions. Island leaders, in turn, are tempted to resort to ideas about 'culture' to explain why those external standards should not apply to them (Larmour, 1997).

\section{The concept of culture}

'Culture', according to Raymond Williams, is 'one of the two or three most complicated words in the English language' (1983, p. 87). In his influential book Keywords, he distinguished three broad usages. The first refers to a process of 
intellectual, spiritual and aesthetic development, which is related to the idea of civilisation. The second focuses on particular ways of life. This focus was adopted by mainstream anthropology, which entails consideration of both the practical and material aspects of a way of life and the signifying and symbolic ones (Kuper, 1999). The third usage is applied more narrowly to artistic and intellectual endeavours, notably theatre, dance, music and film.

The first (developmental) usage seems relevant to the way corruption has been interpreted by development banks and aid donors since the 1990s. For example, Daniel Kaufmann's statistical work for the World Bank finds corruption linked to development (Kaufmann, et al., 1999).

Williams' second usage seems most relevant to the perspective that something regarded as corrupt in one particular culture or subculture might not be regarded as corrupt in another, which raises the issue of 'cultural relativism'.

The third usage, to do with the expressive arts, is particularly relevant to the Pacific Islands. Collective performances cost money and other resources. Participation in cultural events is part of a leader's role and is hard to distinguish from the politics of alliances and democratic electioneering. The TI Sāmoa report, for example, talks about 'pressure to contribute to cultural functions' (So'o, et al., 2004, p. 5).

A recent update of Williams' Keywords warns that 'there is now a good deal of hesitancy over the value of the word culture' (Bennett, et al., 2005, p. 63; but see Sahlins, 1999). The authors note the gradual triumph of Williams' second anthropological meaning (culture as a way of life), often accompanied by rejection of the idea that these ways of life might be fixed, uncontested from within or clearly distinct, as colonial governments in the Pacific Islands are said to have made them.

Two dominant approaches to social science-Marxism and rational choice theory - have tended to deal with 'culture' indirectly. Marxism tended to treat it as an effect of more fundamental economic processes, while rational choice theories try to grasp it through individual attitudes and dispositions. Writing in a Marxist tradition in the 1960s, Colin Leys famously wondered 'what is the problem about corruption?' while explaining how corruption is at the foundation of what US society considers prestigious 'old money' (1965).

The inventor of TI's influential Corruption Perceptions Index, Johann Lambsdorff, has reviewed what he calls empirical research into the cultural determinants of corruption (Lambsdorff, 1999). His analysis tends to focus on individual attitudes and dispositions. He cites a survey conducted by La Porta et al. (1999) that found that trust has a significant negative impact on corruption (Lambsdorff, 1999, p. 12). The same survey also found some positive correlation 
between corruption and membership of a hierarchical religion (Catholic, Orthodox or Muslim) and, it seems, a negative correlation with Protestantism. Lambsdorff concludes his discussion of cultural determinants by stating that '[c]ulture can only explain a certain fraction of the level of corruption and there remains sufficient room for improvements of a country's integrity. Moreover, cultural attitudes can also be a reflection of the organisational patterns that led to their formation' (p. 13).

Believing that 'culture matters', Thompson et al. propose that 'the trouble with taking explicit account of culture is that explanation tends to go out of the window' (2006, p. 322). They identify three typical misuses of the concept that seem relevant to understanding corruption. First, culture can be invoked as an 'uncaused cause' when someone is said to have acted corruptly 'because his culture told him to' (p. 322). But this explanation does not address the prior question of what caused the culture to be like that. Second, culture is invoked as 'an explanation of last resort' (p. 322). That is, having exhausted other explanations for corruption-political, economic, ethical, and so forth-we turn to culture as a kind of residual category, or noise. Third, culture is invoked as a 'veto on comparison' (p. 323). You can't compare, for example, corruption in Australia with corruption in China because each can only be understood in its own terms. Some statements about culture in the Pacific have the same blocking and checking character. To say 'corruption is part of a culture' is not unlike saying 'back off: this is none of your business'.

\section{Culture in the NIS Pacific reports}

Each of the TI NIS reports makes general points about culture and corruption, and typically describes the connection between the two in terms of tensions, contradictions or dilemmas in relationships.

The Solomon Islands report remarks that some village people would regard impartial treatment from an official to whom they were related as 'culturally unacceptable', even insulting, but those familiar with relatives in professional positions do not think this (Roughan, 2004, p. 9). The Fiji report talks of a cultural 'dilemma', in which the official role of public servants is interwoven with and often compromised by their traditional obligations (Singh \& Dakunivosa, 2001, p. 9). In Nauru, 'it may be that tradition and culture also causes corruption' (Kun, et al., 2004, p. 10). The reports on Tonga and Vanuatu both use the metaphor of hiding 'behind the culture' (James \& Tufui, 2004, p. 5; Newton Cain \& Jowitt, 2004 , p. 23). The Vanuatu report stresses that 'Melanesian culture does not 
cause corruption - it does not condone behaviour that benefits an individual at the expense of the community. Instead there is a mismatch between introduced notions of corruption and local culture' (p. 12).

The PNG report says that 'it can be argued that there are certain attributes of the culture which seem to be more compatible with corruption' but is quick to add that 'does not mean that PNG has a corrupt culture' (Mellam \& Aloi, 2003, p. 12). In a similarly circuitous way, the Sāmoa report says that '[a]lthough Sāmoan culture does not necessarily teach corrupt behaviour, the propensity to use public resources and misuse entrusted power have sometimes been associated with the pressure to contribute to cultural functions' (So'o, et al., 2004, p. 5).

Two reports use the positive words 'caring' and 'sharing' in describing local cultural values. The PNG report says that 'sharing and caring is synonymous with leadership in Melanesian culture' and that the traditional responsibilities of a leader include 'mobilisation and distribution of wealth' (Mellam \& Aloi, 2003, p. 11). The Nauru report describes Nauruans as 'by culture a sharing and caring people' (Kun, et al., 2004, p. 11). Similarly, the Fiji report refers to 'the friendly forgiving nature and extreme tolerance inherent in the culture' (Singh \& Dakunivosa, 2001, p. 12).

The Tuvalu report lists important traditional values as: 'reciprocity, status, gift giving, family ties, and community links' (Taafaki, 2004, p. 4). Kiribati culture is characterised as egalitarian (Mackenzie, 2004, p. 4). In the Cook Islands, by contrast, 'the political and social hierarchy ensures that people obey their superiors and political bosses' (Ingram \& Urle, 2004, p. 28).

Traditional cultures are sometimes depicted as in tension with those introduced from the West. In the Marshall Islands, 'many feel as though Marshallese culture heritage has been overridden by American ideologies and materialism' (Pollock, 2004 , p. 12). In describing the operations of a Westminster-based parliament, the Tuvalu report sees an unresolved tension between the 'confrontational style of debating in the Westminster system' and the 'Tuvaluan search for agreement, consensus, value for respect and cooperation' (Taafaki, 2004, p. 6). The result is an ineffective opposition and cabinet members who tend 'to dominate the discussions' in the parliament (p. 6). The authors believe 'the "laid-back" attitude of members in general in discharging their over-sighting and legislative role over public finances is a cause for great concern' (p. 6).

Some reports identify differences within countries. The PNG report points to the country's cultural diversity and notes, for example, that parts of Milne Bay and New Ireland are exceptions to the report's claim that 'traditional political systems have little impact on PNG's political configurations' (Mellam \& Aloi, 
2003, p. 9). The document on the Federated States of Micronesia (FSM) also found strong cultural differences between states and different levels of corruption between them, with Chuuk being regarded as the most corrupt (Hill, 2004, p. 8).

Culture is not always regarded as a factor mitigating or softening accusations of corruption. Particularly in Kiribati, local councils of elders deploy 'the force of culture as the informal anti-corruption system' (Mackenzie, 2004, p. 19). Similarly, village councils in Sāmoa (called fono) deploy sometimes draconian punishments as part of the 'traditional integrity system' (So'o, et al., 2004, pp. $6,26,66)$. Corruption can bear heavily on the consciences of political leaders in Palau: 'strong traditional awareness of right and wrong brings its own pressures, as some suicides of middle-aged men may have resulted from the heavy conscience burden resulting from involvement in corrupt practices that generated quiet, but powerful scorn' (Shuster, 2004, p. 8).

The template required for country reports has forced NIS authors to treat culture as something of a residual category, which was literally added to the TI questionnaire's central focus. They tend to treat culture as an 'uncaused cause', one of the three usages of the concept identified by Thompson et al. (2006, p. 322); however, some reports offer the country's 'smallness' as one explanation for their cultural characteristics (see Larmour \& Barcham, 2006). For example, Tonga's smallness leads to a 'lack of anonymity' that prevents people from lodging complaints (James \& Tufui, 2004, p. 43). Tuvalu is described as 'a small, closely-knit society where family connections and reciprocity provide the basis of social relations', with the result that 'notions of impartiality and independence can be blurred' (Taafaki, 2004, p. 4). In Sāmoa, 'almost all organisations' contain 'people in decision-making capacities who are related or would know someone the decision they are making would affect' (So'o, et al., 2004, p. 12).

The reports also use culture in two more specific senses.

First, culture is seen as something attached to particular institutions - for example, a so-called 'civil service culture'. This interpretation corresponds with Williams' second usage: culture as a way of life in relatively closed and total institutions like the police or the civil service. Similarly, the Solomon Islands report talks of a public service 'ethos of procedure', which (the report argues) was the object of 'active subversion' by politicians like Solomon Mamaloni (Roughan, 2004, p. 10). The Tuvalu report also suggests that civil servants' reluctance to be frank with ministers might reflect a 'cultural problem' (Taafaki, 2004, p. 9).

Second, culture is seen as something pervasive and entrenched, such as a 'culture of corruption' in the forestry industry in Solomon Islands, a 'culture of permissiveness' in Solomon Islands (Roughan, 2004, pp.10, 28) or a 'culture 
of welfare' in Marshall Islands (Pollock, 2004, p. 10). The Fiji report quotes the Ombudsman's remark about a 'culture of silence' that inhibits complaints (Singh \& Dakunivosa, 2001, p. 21). Here the socialised aspect of culture is emphasised, inviting questions about how that culture is learned or could be unlearned. Cultural practices also raised professional problems for a designated 'Cultural Officer' in Kiribati (Mackenzie, 2004, p. 9), where the job presumably dealt with organising dancing and cultural shows-Williams' third sense.

\section{Gifts and bribes}

The first section of this chapter presented an excerpt of the TI sourcebook where Obasanjo argues that it is simple to distinguish a gift from a bribe (Pope, 2000). In an interview with the authors of that country's NIS study, Sāmoa's Prime Minister argued that ' $[\mathrm{w}]$ hat determines an acceptable gift is 5 per cent policy/ law and 95 per cent common sense'. For example, 'a bottle of whisky or ten tala (US\$3.60) would be regarded as an acceptable gift, while a gift of say 3,000 tala (US $\$ 1,080$ ) would certainly be regarded as unacceptable and there would be seen as a bribe' (So'o, et al., 2004, p. 10).

The Sāmoa report explains that 'gift giving has always been a means of obtaining and maintaining political support in Sāmoa's traditional society' (So'o, et al., 2004 , p. 5). The report talks of 'the quality and quantity' of gift-giving as driving the recipient to follow the donor's wishes: 'It is quite normal for a customer to give the employee who is serving him/her during normal duty hours a small amount of money' (p. 10). Similarly, in Tonga, relations of respect 'require the presentation of a gift when making a request of another person, especially a social superior'. Here, 'educated people are now aware that in certain situations such gifts can be construed as bribery' although 'the point at which a traditional gift becomes a bribe is hazy' (James \& Tufui, 2004, pp. 5, 10, 25). Churches also engage in fundraising through 'annual public displays of free gifting' (p. 22). According to Hill, in FSM 'under the cover of tradition' politicians may make 'strategic donations to leaders and customary chiefs, sometimes in relation to a wedding or funeral' (2004, p. 5).

In The gift, Mauss uses anthropological evidence from Melanesia and Polynesia (as well as North America and India) to understand social systems based on systematic and repeated exchanges between collectivities-clans, tribes and families - which often act through chiefs, rather than exchanges between individuals. The most extended form is the famous Kula Ring in what is now Papua New Guinea, where various prestigious forms of shell money are given and received in expeditions around a ring of islands - bracelets moving from west to east and necklaces from east to west (Mauss, 2002 [1950], pp. 27-39). 
In fact, the most intense form of gift-giving was not in the Pacific Islands but in the north-west of what is now US territory. In 'potlatch', chiefs engage in intensely competitive gift-giving. Prestige and honour depend on how much one gives and on repayment with interest of gifts received. At the extreme, valuable goods are publicly destroyed to demonstrate one's wealth and humble one's rivals. The point - as Mary Douglas argues in her foreword to her edition of The gift - is that there is no such thing as a free gift (1990). Gifts create obligations, which is the point of giving them and also a reason one might refuse them. They may look voluntary but in practice are compulsory if one is to survive with honour intact. A milder Western version might be birthday presents.

Mauss sums up the three obligations that underpin a gift economy as follows.

- The obligation to give. Leaders are always obliged to invite their friends, share their food and so on.

- The obligation to accept. Refusal offends, even if it means an added burden.

- The obligation to reciprocate, often with interest. Objects must be passed on, not hoarded. A gift of one blanket must be reciprocated with two (Mauss, 2002 [1950], pp. 50-5). For economists, Mauss estimates rates of interest of '30-100 per cent per year' in potlatch (p. 53).

Some features of this 'war of property' between competing chiefs seem to be continued and reproduced in election campaigns throughout the Pacific region. In Sāmoa, politicians are expected to provide gifts such as school fees to voters and 'in the form of food, fine mats and money' (So'o, et al., 2004, pp. 16, 21). In Niue candidates make 'donations' (Talagi, 2004, p. 5). More generally, in the Marshall Islands 'chiefs and elites are expected to offer services and gifts when available' (Pollock, 2004, p. 11). Ministers also give gifts between elections - for example, when a minister visits an outer island in Tuvalu, local people might offer a feast and, in return, expect one of their 'pet projects' to be funded or shipping schedules to be altered in their favour (Taafaki, 2004, p. 14).

These gifts are not token, spiritual or undemanded, to use Obasanjo's characterisation of the African gift. The politician who has to make such gifts often feels they are excessive, although the reports contain no examples of gifts deemed so excessive that the recipient returned them. In Nauru gifts are a 'legitimate part of the electoral process' (Kun, et al., 2004, p. 10). They may involve traditional items, like the fine mats in Sāmoa, or non-traditional things, like 'fairy lights, a stereo system and a small car' in the Marshall Islands (Pollock, 2004, p. 11).

The third obligation of gift-giving is to pass it on, which is an understudied aspect of corruption. It tends to be assumed that corrupt payments are wasted or consumed (or sent overseas to buy real estate or hidden away in a Swiss bank). 
Clearly, conspicuous waste is part of the north-west American potlatch culture; however, money exchanged may also be usefully invested. A logging company bribes a politician who builds a road, albeit 'in the wrong place' according to planners. Or the politician pays the school fees of the child who later goes to university. We do not yet know enough about the grey or black economy in the Pacific Islands.

The potlatch aspect is especially obvious in gift-giving beyond government. Thus, the Tonga report worries about public ceremonies of 'free gifting' to churches 'despite active policies inveighing against it' (James \& Tufui, 2004, p. 50), and the Tuvalu report is concerned about competition between villages over the size of gifts to retiring church ministers (Taafaki, 2004, p. 22).

\section{Points of entry for cultural factors}

'Culture' can be quite broad and therefore not particularly helpful as a means of understanding notions of corruption. The academic study of public policy often has recourse to the idea of a 'policy cycle' in which problems move through a process of identification, definition, legislation and implementation. Adopting a similar approach helps identify how cultural factors manifest themselves in the Pacific Islands.

\section{In a general public suspicion of corruption}

Writing about South Asia, Gunnar Myrdal talked of the 'folklore of corruption' (1968). The Sāmoan report describes a 'public perception' that is not based on particular evidence (So'o, et al., 2004, p. 11). Rather, perception results from the government's 'secure grip on power' and its track record in the 1990s, which included constitutional amendments to increase the size of cabinet and reduce the Auditor-General's term of office, and the assassination of a minister named in the auditor's reports (p. 11). This suspicion was hard to shake off.

Similarly, the Solomon Islands report uses the phrase 'insidious tolerance' to describe a situation where 'people express suspicion of corrupt activity at the slightest indication, but at the same time are willing to accept inaction concerning that suspicion' (Roughan, 2004, p. 9).

The culture here may be a culture of suspicion, which may be exaggerated or well founded. Its opposite might be the 'trust' that is given such importance by writers on social capital. 


\section{In identifying particular people or behaviour as corrupt}

This is the point at which people consider whether a particular action or inaction is corrupt. It should be noted that it may also be decided that this line of action is bad for reasons other than because it is corrupt. The decision that something is corrupt might appear to be an isolated occurrence but is in fact a social event. The decision involves language, and in practice is likely to involve discussion with colleagues, friends, family or some kind of internal dialogue that reproduces these interactions. The process of consideration may refer to what others have done before or would do. It may invoke role models, childhood injunctions and the lessons to be learned from folktales, literature or film.

In Vanuatu and Nauru, for example, it seems that only the givers-not the receivers - of bribes are seen as acting corruptly. In Vanuatu: 'in the popular perception, ordinary people who receive bribes are not "corrupt". Chiefs who tell individuals how to vote after receiving bribes or goods for their villages are sometimes perceived as corrupt, but not always. The person offering the bribe is, however, acting corruptly' (Newton Cain \& Jowitt, 2004, p. 10).

Similarly in Nauru, people encouraging or benefiting from corruption tend not to be regarded as corrupt. Where people are paid to vote one way or another, 'the blame attaches to the person who offers the temptation rather than the person who accepts it' (Kun, et al., 2004, p. 9).

\section{In the seriousness with which corruption is taken}

An important part of any anti-corruption policy is to assess how serious corruption is, but this is complicated by the fact that assessments vary. Nongovernmental organisations (NGOs) now imbue any discussion of corruption with a deadly earnestness, but corruption may be taken less seriously by recipients than by donors. Epeli Hau'ofa created several tales around the fun of fooling donors in an imaginary Pacific Island country very like Tonga (1994).

Some assessment of seriousness is necessary for any practical action, which has costs in fractured social relationships and police time. It is easy for an agency or campaign to get bogged down in trivial examples and miss more serious manifestations.

According to the country reports, in FSM people don't think that misappropriated money has been 'taken out of the pockets of citizens' (Hill, 2004, p. 12). In Nauru, carelessness may have been higher when people thought 'resources were in abundance' (Kun, et al., 2004, p. 11). In Vanuatu, 'grassroots' people see the activities of law and government as 'irrelevant to their everyday life' and they therefore do not 'place any burden of expectation on their leaders' (Newton Cain 
\& Jowitt, 2004, p. 5). They become concerned only when they see their own money is at stake, as in the case of the 1998 riots in Vanuatu, which followed a report by the Ombudsman revealing that although 33000 people were members of the National Provident Fund, there were only 784 applications for housing loans, of which only 150 were successful. The majority of the beneficiaries 'were Ministers, members of parliament, Vanuatu Provident Fund Board members and staff, UMP party supporters (the UMP was the dominant party in Government at the time), political appointees and families of these groups' (Newton Cain \& Jowitt, 2004, p. 14). Many of the favoured groups had loans approved without even submitting applications, while many other applications were never considered (p. 14).

\section{In the willingness to criticise and report corruption}

The Cook Islands report talks of 'fear of reprisal': 'people would rather live with the consequences of corrupt politicians than face losing their jobs' (Ingram \& Urle, 2004, p. 12). In Palau, 'people find it difficult to correct or discipline or even report that a friend, relative or co-worker is behaving in a corrupt manner...Quiet and subtle scorn' are preferred to overt rebuke, and 'indirectness is a virtue' (Shuster, 2004, pp. 8-9). In Tonga, people won't report others to avoid 'shame to the family involved, damage to the social fabric, and the breaking of relationships' (James \& Tufui, 2004, p. 10). In FSM, 'it is very improper to question or openly criticise others or cause someone to lose face' (Hill, 2004, p. 11).

In the Solomon Islands, there has been 'lack of public or institutional pressure to redress blatant corruption acts' (Roughan, 2004, p. 11). The report points to 'a marked unwillingness of leading individuals' in the relevant institutions (p. 11). The Fiji report argues that in small societies with strong cultural ties 'everyone knowing each other makes the act of ignoring illegal practices easier than "blowing the whistle"' (Singh \& Dakunivosa, 2001, p. 9).

The Cook Islands report talks of 'the traditional practice of respect for elders and leaders that leads to reluctance to question their actions' (Ingram \& Urle, 2004, pp. 5, 12). In FSM there is 'reluctance to openly criticise others, particularly chiefs' (Hill, 2004, p. 8). The Nauru report follows the same line, and states that 'traditionally, Nauruans do not question the actions and behaviour of their chiefs out of respect or fear or both' (Kun, et al., 2004, p. 12). The 'welfare and cohesion of the extended family' are held more dearly than the putative cost to the country (p. 12). In Vanuatu, 'tradition discourages the criticism of leaders' (Newton Cain \& Jowitt, 2004, p. 5).

In FSM, 'traditional deference', for example, might make a customs officer 'unlikely to closely question or search a chief arriving in the country from 
abroad' (Hill, 2004, p. 12). It was also suggested, however, that people were reluctant to report corruption less from fear of reprisal than from the expectation that they will 'get their chance' to benefit corruptly next (p. 12).

\section{In reaching authoritative decisions about corruption}

The report on Tonga found that people can 'hide behind the culture' because there were no authoritative guidelines to 'distinguish between cultural practice and corruption' (James \& Tufui, 2004, p. 5). The report suggested that a planned code of conduct for public servants might improve the situation (p. 5). Courts in Kiribati have been particularly engaged in drawing lines between appropriate and inappropriate gift-giving, and are required to take custom into account in deciding cases (Mackenzie, 2004, p. 6). In 1997, following a series of cases involving ministers and campaigns (see Larmour, 1997), the Kiribati electoral ordinance was amended as follows: 'any person making a customary offering to a Maneaba [meeting house] referred to in I-Kiribati as "Mweaka", "Moanei" or "Ririwete", with the sole intention of showing respect for the customs and traditions of Kiribati, shall not be guilty of bribery' (Mackenzie, 2004, p. 9).

The Kiribati courts have also become involved in distinguishing between 'respect for customs and tradition' and 'intention to influence voters' (p. 9). For example, the custom of bubuti makes it 'acceptable for someone lacking in [certain] resources to make a specific request to another who is better endowed' (Mackenzie, 2004, p. 9, quoting Chief Justice Williams, 15 October 2003). Such requests had been made in the form of a fine demanded of a candidate visiting a Maneaba, and had involved gifts like a chainsaw or a video set. In the case before the High Court, it was decided that the issue depended on the intention of the giver and that the gifts 'were made because of custom. The candidates had no choice' (Mackenzie, 2004, p. 9).

In a similar case in Tuvalu - where a candidate had provided chiefs with food and drink prior to a by-election, and chiefs had promised their villagers' votes in return - the High Court found the feasting to be in accordance with custom rather than 'corrupt practices' (Taafaki, 2004, p. 15).

\section{In enforcing existing laws against corruption}

Most countries in the region have laws prohibiting bribery and other instances of corruption. The laws are often part of the criminal code, which police are responsible for enforcing; however, police can exercise a great deal of discretion in deciding whether to investigate and-later-prosecute alleged offences. While police may be corrupt themselves, the complaints in the NIS studies tended to focus on matters of competence and professionalism, rather than police 
corruption. In FSM, however, police were reported as failing to implement the law against relatives, and in Papua New Guinea police performance was 'watered down by lack of capacity, political influence and regionalism' (Hill, 2004, p. 14; Mellam \& Aloi, 2003, p. 27).

\section{In punishing corruption}

The Cook Islands report notes in relation to a recent successful prosecution for secret commissions that 'public attitudes are often sympathetic' to the person found guilty (Ingram \& Urle, 2004, p. 12). People often said things like 'we feel sorry for his children', 'how much did the community lose from his criminal actions?' and 'the community did not suffer any loss' (p. 12). There were no obvious victims, so principles of restorative justice might have suggested leniency.

In Nauru, people who are the subject of headlines or gossip 'continue to be reelected' (Kun, et al., 2004, p. 9). In Papua New Guinea it was reported that 'it is very unlikely for disgraced ministers to be re-elected', two notable exceptions being the dismissal of two ministers in 1991 (Ted Diro) and 1992 (Melchior Pep) and their re-election (respectively) in 1997 and 2002 (Mellam \& Aloi, 2003, pp. 32-3). In FSM, 'a willingness to ignore or forget transgressions by leaders' was reported (Hill, 2004, p. 8). In Vanuatu, people who have been damned in Ombudsman Commission reports 'continue to get elected' (Newton Cain \& Jowitt, 2004, p. 10). And in Nauru, every time a new president is elected, there is a batch of presidential pardons (Kun, et al., 2004, p. 18).

In Kiribati, however, it was reported that a decline in cultural sanctions such as ostracism of those involved in theft was contributing to the rise of petty corruption among junior officials (Mackenzie, 2004, p. 10).

\section{Other issues in the relationship between culture and corruption}

Cultural arguments can be excessively deterministic, treating people as 'dopes' who are just following orders. Corruption often presents itself as a dilemma between two ethical claims - for example, between the claims of office and family.

Some of the calculation involves rehearsing how a person will explain or justify what they did if there is a complaint about corruption, with cultural concerns determining the actual factors that people take into account and how they are weighed. 
In this vein, Barbara Reid studied how Sāmoans and Europeans in New Zealand judged a series of vignettes of common ethical dilemmas. Looking for differences in ethical style, she identified reasoning processes, justifications and implicit ethics (1990). Generally, she found that people from different cultures were equally principled in their moral reasoning but differences arose in the contexts in which particular principles were applied. Differences existed among Sāmoans according to their differential acculturation within New Zealand society and to a 'lack of consensus in Sāmoan culture' about how certain moral problems should be solved. Finally - and here is the crunch-'cultural differences in moral reasoning are due to a contrast between a socio-centric world view on the part of Sāmoans and the more ego-centric world view of Europeans' (Reid, 1990, p. 53). Other things being equal, Sāmoans tended to give greater weight to the social consequences of actions, while Europeans tended to give greater weight to individual consequences.

So far we have been treating 'cultures' as specific to particular countries (Sāmoa, Tonga, and so on) but as similar within national boundaries. In fact, most countries are multicultural — and the Pacific Islands are no exception. Suspicions and accusations of corruption can occur along social frontiers and can be said to mark differences between 'us' and 'them'. Evers and Mehmet propose that accusations of corruption in South-East Asia arise from a distinct division of labour between 'trading minorities' (such as the Chinese) and indigenous cultures, which value caring and sharing, redistribution and honour over profit (1994). The latter faced a 'trader's dilemma': how to prosper economically while preserving respected subsistence-based traditions.

The dilemma was resolved, say Evers and Mehmet, by partnering with ethically suspect traders, who 'did the dirty work'. According to the country reports, similar divisions of labour seem to have been taking place between Chinese, Vietnamese and other Asian minorities and indigenous leaders in many parts of the Pacific. Similarly, the contrast between supposedly competitive Indo-Fijians and 'caring and sharing' indigenous Fijians is often belied by business alliances between them. In these cross-cultural situations, corruption can be interpreted broadly as an undignified pursuit of profit, which is best done at arm's length through ethically and ethnically distinct intermediaries. In Mauss's terms, the honour gained in the gift economy needs to be insulated from contaminating investment in the money economy. A tight system of exchange and indebtedness underlies the apparently voluntary friendship of an indigenous leader and their adviser(s) because they desperately need one another.

The Cook Islands report refers to dubious foreigners - a New Zealander 'investor' in this case - with financial connections to politicians who protect him from scrutiny by the Immigration Department (Ingram \& Urle, 2004, p. 9). The Solomon Islands report connects the arrival of Asian logging companies 
with a sharp increase in the level of corruption, including a 1994 leadership code case in which a logging company allegedly bribed two ministers to defect from the government (Roughan, 2004, p. 29). The Marshall Islands report blames 'Asian business procedures' for increases in corruption, particularly in the fishing industry (Pollock, 2004, p. 11).

Another form of corruption linked to multiculturalism is 'affirmative action' programs designed to advance indigenous people but which often become a focus for individualised corruption. For example, the Fiji report worries that 'it has been difficult to determine the extent of nepotism and cronyism in the backdrop of existing policies on affirmative action' and that 'if nepotism and cronyism are not quickly identified and addressed, they could easily become part of the system in the closely knit society as exists in Fiji' (Singh \& Dakunivosa, 2001, p. 7).

Most of the NIS reports equate local culture with tradition; however, the Vanuatu report points to modern as well as traditional culture (Newton Cain \& Jowitt, 2004, pp. 11, 26, 62). The Solomon Islands report mentions the growing influence of young people - and the perceived social problems this generates (Roughan, 2004, p. 7).

A distinction between popular and elite culture parallels the distinction in the corruption literature between petty and grand corruption. Petty corruption consists of small, routine payments made to poorly paid junior officials simply to do their job. It is often illegal, but may be accepted as necessary by both sides in the transaction. Grand corruption consists of larger, more secretive payments made to ministers and senior officials to secure such things as contracts.

Sociologists and anthropologists are pursuing a new strand of qualitative study on corruption, which helps refine and elaborate this distinction. They are interested in popular and informal understandings of corruption, the differences between the law and popular opinion on what counts as corruption, and how much corruption matters to whom. Alena Ledeneva, a sociologist writing about the former Soviet Union, analyses a system of low-level exchanges of favours (blat) through which people work around bureaucratic difficulties and mobilise relatives and acquaintances to 'get by' (1998). Elisabeth Harrison (2004) relates corruption to the responsible exercise of official discretion by field officers in Africa, while Akhil Gupta (1995) looks sympathetically at the role of middlemen between clients and bureaucrats in India.

Petty or popular corruption seems less widespread in the Pacific Islands compared with other parts of the developing world. The reports found it in only three or four countries, although it may be growing. The PNG report remarked on the practice of making small payments 'to speed up enquiries and service delivery' 
(Mellam \& Aloi, 2003, p. 15). The use of belittling euphemisms to describe these payments - 'six packs' of beer or 'bus fares' - seemed to suggest ethical uneasiness. The Fiji report found what it called 'kickbacks' being demanded for all sorts of licensing: passports, work permits and drivers' licences (Singh \& Dakunivosa, 2001, p. 6). In Sāmoa, giving small gifts to government employees for services rendered was 'normal', as noted above (So'o, et al., 2004, p. 47). The Tonga report quotes a government minister saying that 'departmental heads often augment the salaries of their low-paid staff from their own pockets in order to encourage them to come to work, work on time, or carry out their functions efficiently' (James \& Tufui, 2004, p. 35).

The anthropological and sociological research cited above is sympathetic to popular forms of corruption, which are seen as necessary for 'getting by'. In contrast, grand corruption is often characterised as a crime of the powerful against 'the people', who are typically cast as innocent victims.

Ordinary people, however, may also be participants in and beneficiaries of grander forms of corruption. Writing about the Pacific Islands, Ron Crocombe argues that '[p]eople do not approve of corruption in principle, nor generally in practice, unless they benefit from it. Even then they may condone it, or rationalise it on other terms, rather than approve of it' (2001, p. 516).

That's probably true everywhere. Politicians often hold this jaundiced view of people, at least as voters and constituents. For example, the PNG MP Dame Carol Kidu wrote to a PNG newspaper defending colleagues under the Ombudsman's scrutiny for expenditures in their constituencies and describing the pressures that constituents place on MPs:

Because aspects of the bureaucratic machinery are dysfunctional, people who should be going to the bureaucracy instead go to the politician for water, roads, clinics, school fees and endless needs that should not be seen as MPs' functions. Some people are desperate and some are demanding, threatening and aggressive (my staff have sometimes faced weapons and even rape threats).

There is a popular perception that politicians become rich. But how many ex-politicians (or serving politicians) are rich? Many are struggling to survive because their businesses were destroyed by politics or they gave away most of what they earned as a politician - not as bribes but because they feel a Melanesian obligation and compassion for the situation many people are in. $(2006)^{1}$

1 I am grateful to Bill Standish for bringing this letter to my attention. 
Popular corruption intersects with other popular scams, gambling and getrich-quick schemes that operate on a grander scale than petty corruption. The Solomon Islands report mentions 'fraudulent schemes' that have been rife in the region, with varying degrees of legality and sanction by regulators (Roughan, 2004, p. 9). Such schemes range from chain letters to the pyramid investment scheme known as 'U Visitract', in which the widely respected PNG Ombudsman was found to be personally involved, and consequently resigned. The perpetrators - such as Noel Misingu in Papua New Guinea-can even become folk heroes.

It is often hard to draw lines between these popular schemes, the dubious projects that attract ministers and national get-rich-quick schemes that get domestic legal sanction - for example, the tax havens in Vanuatu, Cook Islands and Nauru. Among such dubious schemes, the Tuvalu report frets about official attempts to market Tuvalu's Internet domain name, 'dot $t v^{\prime}$, in the United States (Taafaki, 2004, p. 8).

When popular culture is indifferent (as in Vanuatu) or sympathetic to some forms of corruption, it raises questions for a standard aid donor strategy of relying on an angry population to induce reluctant politicians to grasp the 'political will' to attack corruption. As we have seen, popular grumbling about 'corruption' is relatively common, and anger against elites can be easily mobilised. But, in fact, popular opinion often seems to be ambivalent. It is against corruption but approves of politicians who provide support for local or personal events and of timber companies who promise development. And in Papua New Guinea, according to Kidu, this ambivalence is heightened by popular fatigue with politicians and the increasing failure of the government to deliver.

Elite culture is the opposite of popular culture. In its anti-corruption strategies, TI's style is deliberately elitist. It works through coalition building, seminars and quiet lobbying, rather than demonstrations in the street. Williams' first sense of the word 'culture', referring to a process of spiritual and aesthetic development, was closely linked to ideas about 'civilisation'. Here the sociologist Norbert Elias's (1998) arguments about a 'civilizing process' seem to be relevant to discussions about corruption in several ways (Larmour, 2006). Elias was writing about the development of European states, noting that the successful monopolisation of power was accompanied by a social and even psychological process of elite 'self-restraint' whereby warriors became courtiers. Bodily functions became hidden behind screens. Violence became stylised, and hidden. This civilising process was not directed, but emerged, and it could easily go into reverse (as in Nazi Germany). It happened to have taken place in Europe, China and other places, but could take place in any part of the world. In the Pacific, the centralisation and monopolisation of power by the Hawaiian monarchy, and the parallel growth of an elaborate court politics, are good examples of civilising 
processes. Some chiefly virtues seem to be of the restrained and dignified kind that Elias identifies. Its dark side lies in the violence that is displaced offstage onto serfs and commoners, and in wars against other chiefs.

The current international turn against corruption involves and seeks a shift in values within elites. Often it is an intergenerational shift, as the sons and daughters of the first generation of nationalist leaders turn against corruption (and join the local branch of TI). Corruption is now something about which elites are becoming faintly ashamed. It is felt to be something 'we used to do in the past'. If we do it now it is done secretly, shamefully and is screened from the public gaze. If Elias is correct, these elite values - and the social constraint towards self-restraint - may become generalised throughout society. Corruption may become less visible, but it won't necessarily go away. It should be noted that Elias also points to the link between self-restraint and state-building. If states 'fail', there is no guarantee that the civilising process will not go into reverse with elites resuming their outwardly rapacious ways.

\section{Conclusions}

Despite attacks on cultural relativism, and the universalistic doctrines of TI and the international community, ideas about culture still seem useful in understanding how people recognise and respond to what is judged to be corrupt behaviour. These reflections on culture do not deny the ethical basis of judgments about corruption. Rather, they show how ethical meanings develop and change, how people give different weight to different factors in weighing up what is the right thing to do, and to how they may displace onto others the ethical load of doing business. Anti-corruption practices need to adapt to this more nuanced picture of how different people decide to behave.

\section{Acknowledgements}

I am grateful for comments on an earlier draft of this paper to Geoff White, Raymond Apthorpe, Manu Barcham and Ashwin Raj. Any faults remain my own. A version of this chapter was published in the journal Crime Law and Social Change (Larmour, 2008) and in a recent monograph on the subject of corruption in the Pacific (2012). 
Corruption: Expanding the focus

\section{References}

Alatas, Syed Hussein. (1968). The sociology of corruption: the nature, function, causes and prevention of corruption. Singapore: D. Moore Press.

Bennett, Tony, Grossberg, Lawrence, \& Morris, Meaghan (Eds). (2005). New keywords: a revised vocabulary of culture. Malden and Oxford: Blackwell.

Crocombe, Ron (2001). The South Pacific (3rd edn). Suva: University of the South Pacific.

Douglas, Mary. (1990). Foreword. In Marcel Mauss (Ed.), The gift: the form and reason for exchange in archaic societies (2nd edn, pp. ix-xxiii). Abingdon: Routledge.

Elias, Norbert. (1998). On civilization, power and knowledge: selected writings. Stephen Mennel \& Johan Goudsblom (Eds). Chicago and London: University of Chicago Press.

Evers, Hans-Dieter, \& Mehmet, Ozay. (1994). The management of risk: informal trade in Indonesia. World Development, 22(1), 1-9.

Gregory, Chris A. (1982). Gifts and commodities. London: Academic Press.

Gupta, Akhil. (1995). Blurred boundaries: the discourse of corruption, the culture of politics, and the imagined state. American Ethnologist, 22(2), 375402.

Harrison, Elizabeth. (2004). The 'cancer of corruption'. In Italo Pardo (Ed.), Between morality and law: corruption, anthropology and comparative society (pp. 135-54). Aldershot: Ashgate.

Hau'ofa, Epeli. (1994). Tales of the Tikongs. Honolulu: University of Hawai'i Press.

Hill, Edward R. (2004). Federated States of Micronesia national integrity systems: country study report. Blackburn South: Transparency International Australia.

Ingram, Takiora, \& Urle, Mathilda. (2004). Cook Islands national integrity systems: country study report. Blackburn South: Transparency International Australia.

James, Kerry, \& Tufui, Taniela. (2004). Tonga national integrity systems: country study report. Blackburn South: Transparency International Australia.

Kaufmann, Daniel, Kraay, Art, \& Zoido-Loban, Pablo. (1999). Governance matters. Policy Research Working Paper Series 2196. 
Kidu, Carol. (2006). Letter to the editor. The National, 7 March.

Kun, Ruben, Togomae, Whitlam, \& Kun, Roland. (2004). Nauru national integrity systems: country study report. Blackburn South: Transparency International Australia.

Kuper, Adam (1999). Culture: the anthropologists' account. Cambridge: Harvard University Press.

Lambsdorff, Johann Graf. (1999). Corruption in empirical research-a review. Paper presented at the 9th International Anti-Corruption Conference, 10-15 December, Durban, South Africa.

La Porta, R., Lopez-de-Silanes, F., Shleifer, A., \& Vishny, R. W. (1999). The quality of government. Journal of Law, Economics and Organization, 15(1), pp. $222-79$.

Larmour, Peter. (1997). Corruption and governance in the South Pacific. Pacific Studies, 20(3), 1-17.

Larmour, Peter. (2006). Civilizing techniques: Transparency International and the spread of anti-corruption. In Len Seabrooke \& Brett Bowden (Eds), Global standards of market civilisation (pp. 97-106). London: Routledge.

Larmour, Peter. (2008). Corruption and the concept of 'culture': evidence from the Pacific Islands. Crime, Law and Social Change, 49, 222-39.

Larmour, Peter. (2012). Interpreting corruption: culture and politics in the Pacific Islands - topics in the contemporary Pacific. Honolulu: University of Hawai'i Press.

Larmour, Peter, \& Barcham, Manuhuia. (2006). National integrity systems in small Pacific Island states. Public Administration and Development, 26, 176-84.

Ledeneva, Alena. (1998). Russia's economy of favours: 'blat', networking and informal exchange. Cambridge: Cambridge University Press.

Leys, Colin. (1965). What is the problem about corruption? Journal of Modern African Studies, 3(2), 215-30.

Mackenzie, Ueantabo Neemia. (2004). Kiribati national integrity systems: country study report. Blackburn South: Transparency International Australia.

Mauss, Marcel. (2002 [1950]). The gift: the form and reason for exchange in archaic societies (W. D. Halls, Trans., 2nd edn). Abingdon: Routledge. 
Corruption: Expanding the focus

Mellam, Albert, \& Aloi, Daniel. (2003). Papua New Guinea national integrity systems: country study report. Blackburn South: Transparency International Australia.

Myrdal, Gunnar. (1968). Asian drama: an inquiry into the poverty of nations. New York: Atheneum.

Newton Cain, Tess, \& Jowitt, Anita. (2004). Vanuatu national integrity systems: country study report. Blackburn South: Transparency International Australia.

Pollock, Nancy J. (2004). Republic of the Marshall Islands national integrity systems: country study report. Blackburn South: Transparency International Australia

Pope, Jeremy. (2000). TI source book 2000. Confronting corruption: the elements of a national integrity system. Berlin and London: Transparency International.

Reid, Barbara. (1990). Weighing up the factors: moral reasoning and culture change in a Samoan community. Ethos, 18(1), 48-71.

Roughan, Paul. (2004). Solomon Islands national integrity systems: country study report. Blackburn South: Transparency International Australia.

Sahlins, Marshall. (1999). Two or three things I know about culture. Journal of the Royal Anthropological Institute, 5(3), 399-421.

Secretariat of the Pacific Community. (2012). Population estimates and projections for several years. Pocket statistical summary 2011. Nouméa: Secretariat of the Pacific Community.

Shuster, Donald R. (2004). Republic of Palau national integrity systems: country study report. Blackburn South: Transparency International Australia.

Singh, H. P., \& Dakunivosa, Mosese. (2001). Fiji national integrity systems: country study report. Blackburn South: Transparency International Australia.

So'o, Le'apai L. Asofou, Sinclair, Ruta-Fiti, Va'a, Unasa L. F., \& Lāmeta, Sonny. (2004). Sāmoa national integrity systems: country study report. Blackburn South: Transparency International Australia.

Taafaki, Tauaasa. (2004). Tuvalu national integrity systems: country study report. Blackburn South: Transparency International Australia.

Talagi, Mary. (2004). Niue national integrity systems: country study report. Blackburn South: Transparency International Australia. 
Thompson, Michael, Verweij, Marco, \& Ellis, Richard J. (2006). Why and how culture matters. In Robert E. Goodin \& Charles Tilly (Eds), The Oxford handbook of contextual political analysis (pp. 319-40). Oxford: Oxford University Press.

Williams, Raymond. (1983). Keywords: a vocabulary of culture and society (rev. edn). New York: Oxford University Press. 